\title{
The Biochemical Status of $\mu$ Particles in Paramecium aurelia
}

\author{
BY I. STEVENSON* \\ Institute of Animal Genetics, West Mains Road, Edinburgh 9, Scotland
}

(Accepted for publication 7 March 1969 )

\begin{abstract}
SUMMARY
$\mu$ particles of stock 540 (syngen I) of Paramecium aurelia were isolated and studied. Electron microscopy showed that isolated $\mu$ particles were very similar to bacteria in fine structure, the general appearance being similar to that found by earlier workers. Contamination of the preparations with other cell particles and with the paramecium food bacteria was low. The isolated $\mu$ particles contained DNA, RNA, protein and probably carbohydrate and lipid. The DNA of the particles was characterized by density-gradient centrifugation in $\mathrm{CsCl}$ and by determination of $\mathrm{Tm}$. The density of the DNA was estimated to be 1.694 g./c.c., a value very similar to that for the DNA of Paramecium aurelia 540 macronuclei, which was estimated to be $\mathrm{I} \cdot 693 \mathrm{~g}$./c.c. The Tm was likewise similar, being $82 \cdot 0^{\circ}$, against $81 \cdot 8^{\circ}$ for Paramecium macronuclear DNA. However, this DNA was associated with the $\mu$ particle, as no such DNA could be prepared from genotypically identical $P$. aurelia which did not possess $\mu$ particles, and the DNA associated with the $\mu$ particles was not susceptible to DNase action on treatment of isolated $\mu$ particles with the enzyme before DNA extraction. Hence it seems that the $\mu$ particle has a membrane-protected DNA of a similar buoyant density to the $P$. aurelia DNA. Isolated $\mu$ particles possessed an active DNA-dependent system capable of the incorporation of ribonucleoside triphosphates into an acidinsoluble product. The reaction needed the presence of ATP, GTP, and UTP for optimal activity, and had an absolute dependence on $\mathbf{M g}^{2+}$. The reaction was inhibited by actinomycin $\mathrm{D}$, and a ribonuclease-sensitive product was synthesized.
\end{abstract}

\section{INTRODUCTION}

Many stocks of the ciliate Paramecium aurelia have been observed to possess cytoplasmic particles. The possession of these particles may be correlated with a killing or mate-killing ability of the bearer animal upon stocks of paramecia that do not bear particles. These particles have been the subject of much experiment and speculation, and a general conclusion has been reached that they are bacterium-like endosymbiotes (Sonneborn, 1959; Beale \& Jurand, 1960, 1966; van Wagtendonk, Clark \& Godoy, I963).

The $\mu$ particle of stock 540 (syngen I) of Paramecium aurelia was studied by Beale \& Jurand (I960) by electron microscope and cytochemical techniques; their results clearly indicate that this particle may be an endosymbiotic bacterium. Van Wagtendonk, Clark \& Godoy (1963) succeeded in culturing the lambda particle of stock 299 (syngen 4) in a complex medium outside the host cell, while van Wagtendonk \& Tanguay (1963) showed that DNA, RNA, protein, carbohydrate and lipid were present in isolated lambda particles.

* Present address: Research School of Biological Sciences, Australian National University, Canberra City, A.C.T., Australia. 
The most extensively studied particle, the kappa particle of stock 5I (syngen 4), resembles a bacterium in many respects, but shows some unusual features; it has two forms, bright (B) particles containing a refractile or $\mathrm{R}$ body, and non-bright or $\mathrm{N}$ particles. Kappa of stock 7 (syngen 2) also seems like this. B particles are responsible for the killing effect, while $N$ particles are the reproductive body (Smith, 196I; Mueller, 1962). In the electron microscope, the $\mathbf{R}$ body has the appearance of a tightly coiled roll which can suddenly and quickly unroll to form a twisted ribbon about I $5 \mu$ long (Anderson, Preer, Preer \& Bray, 1964; Preer, Hufnagel \& Preer, I966). Possession of this singular body would seem to distinguish the kappa particles of stocks $5 \mathrm{I}$ and 7 from the other particles, in which no such structures have been observed.

In the present paper, results of some studies on isolated $\mu$ particles of stock 540 are presented which provide further evidence for the bacterial nature of this particle. A partial account of this work has previously been published (Stevenson, 1967a), and an abstract presented (Stevenson, 1967b).

\section{METHODS}

\section{Stocks of Paramecium used and culture medium}

The following stocks of Paramecium aurelia were used: stock 540, bearing $\mu$ particles (mate-killer); stock 540, not bearing $\mu$ particles (sensitive), derived from stock 540 bearing $\mu$ particles by prolonged culture at $3 \mathrm{I}^{\circ}$. The presence or absence of $\mu$ particles is the sole difference between these two stocks. Genetically they are identical.

Paramecia were maintained at $18^{\circ}$ in $\mathrm{I} 1$. batches of lettuce extract medium (pH 6.8) in 3-1. flat culture flasks. The lettuce extract was prepared as described by Sonneborn (1950). Paramecia were subcultured every 3 weeks. This method was found to be more reliable for prolonged particle maintenance than slide-cultures, and decreased the labour involved in setting up large cultures. Autogamy was induced at 3-month intervals, and fresh maintenance cultures set up from ex-autogamous clones.

Mass cultures were grown and harvested as described by Jones (1965), except that growth was at $25^{\circ}$ for 5 days; 501 . of culture were normally grown. After harvesting, the paramecia were washed twice with the solution described by Dryl (I959).

Paramecia were tested for particles at all stages of growth, and at subculture and autogamy, by the method described by Beale \& Jurand (1966).

\section{Isolation of $\mu$ particles}

Washed paramecia were suspended in 4 volumes of ice-cold Dryl solution and homogenized by using a Tri-R stirring motor (Tri-R Instruments, Jamaica, New York, U.S.A.), for 20 to 30 strokes of a teflon pestle. Homogenization was examined under a binocular microscope; it was considered complete when fewer than I \% whole paramecia were left. The homogenate was centrifuged at $35,000 \mathrm{~g}$ for $7 \mathrm{~min}$. (MSE HS I 8 centrifuge) and the pellet was suspended in $40 \mathrm{ml}$. of $0.0 \mathrm{I} \mathrm{M}-\mathrm{Na}$ phosphate (pH 6.8). The supernatant fluid was discarded.

Body and cell-wall fragments, trichocysts and many cilia were removed by passing the suspension of pellet material through a column of cellulose (Preer et al. 1966). During the preparation and centrifugation of the homogenate, 15 to $20 \mathrm{~g}$. of cellulose (Whatman cellulose powder CF I I) were stirred into $200 \mathrm{ml}$. of the phosphate buffer 
and then poured into a $40 \mathrm{~cm} . \times 2.5 \mathrm{~cm}$. chromatography column. The column of cellulose was washed with $200 \mathrm{ml}$. of buffer. After draining to bed level, the re-suspended $35,000 \mathrm{~g}$ pellet was rapidly applied by using air pressure, then fresh buffer was added above the cellulose, and the column was washed with further buffer, using a peristaltic pump to speed the flow. The eluate was collected till it was no longer visibly turbid. On examination in the phase-contrast microscope it was seen to contain mitochondria, a small number of cilia, a few Aerobacter aerogenes and the $\mu$ particles. Usually, about $5 \times 10^{8} \mu$ particles $/ \mathrm{ml}$. were present, with a similar or rather larger number of mitochondria.

The eluate was centrifuged at $22,000 \mathrm{~g}$ for $15 \mathrm{~min}$. and the pellet suspended in $9 \mathrm{ml}$. of the phosphate buffer; $3 \mathrm{ml}$. of this suspension were layered over a Io to $40 \%$ (w/v) gradient of Ficoll (Pharmacia, Uppsala, Sweden) in a thin-walled polypropylene centrifuge tube. Gradients were $32 \mathrm{ml}$. and were prepared by layering 10, 20, 30 and $40 \%$ Ficoll in the tubes 18 to $24 \mathrm{hr}$ before use, then keeping at $4^{\circ}$. Three gradients were normally run.

Gradients were centrifuged at $10,000 \mathrm{rev} . / \mathrm{min}$. (10,500 $\mathrm{g}$ av.) in the $3 \times 40 \mathrm{ml}$. swingout rotor of the MSE 'Superspeed 50' ultracentrifuge, for $45 \mathrm{~min}$. After centrifugation the particles could be seen as a distinct band in the gradients. This band was only present in preparations from stock 540 mate-killers; preparations from stock $54^{\circ}$ sensitive did not show it.

Gradients were fractionated with a 5-ml. syringe and blunt-tipped $18 \mathrm{G}$. needle $(5 \mathrm{~cm}$.). Six fractions of $3 \mathrm{ml}$. each were removed. The fractions were examined at $\times 800$ under phase-contrast; $\mu$ particles, when present, were in fraction 4 from the top. The fractions bearing $\mu$ particles were pooled and centrifuged at $38,000 \mathrm{~g}$ for $\mathrm{I} 0 \mathrm{~min}$. to pellet the $\mu$ particles. The pellet was washed once with phosphate buffer and recentrifuged. Finally the pellet was washed with distilled water or an appropriate buffer.

With the exception of the cellulose column step, which was done at about $20^{\circ}$, all preparative steps were at 0 to $4^{\circ}$.

\section{Techniques for electron microscopy}

$\mu$ particles were prepared for electron microscopy by a method very similar to that of Kellenberger, Ryter \& Séchaud (1958). $\mu$ particles were fixed in veronal+acetate buffered $\mathrm{OsO}_{4}+\mathrm{CaCl}_{2}$ to $0.00 \mathrm{I} \mathrm{M}$, the fixative given by these authors. The particles were embedded in $2 \%(\mathrm{w} / \mathrm{v})$ agar, washed in the veronal + acetate buffer + uranyl acetate, dehydrated through ethanol and embedded in Araldite. Sections were cut at 500 to $800 \AA$ with a Porter-Blum Servall microtome, the sections were stained with lead citrate (Reynolds, 1963$)+2 \%(w / v)$ uranyl acetate and then examined with either a Philips EM 75 or AEI EM 6 electron microscope.

\section{Chemical methods}

DNA was estimated by the diphenylamine reaction as modified by Burton (1956). RNA was estimated by the orcinol reaction (Ogur \& Rosen, 1950) and protein by the method of Lowry, Rosebrough, Farr \& Randall (195I). Carbohydrate was estimated by the anthrone reaction and lipid by the silver dichromate reaction (Bloor, 1947). Lyophilized material was used as starting material for these assays. 


\section{Preparation of DNA}

DNA for use as standards was prepared from spray-dried Micrococcus lysodeikticus (Cambrian Chemical Co., London, S.E. I6), from Aerobacter aerogenes strain A3(0) (a rough strain used as food organism for the Paramecium in all these experiments) and from isolated macronuclei of Paramecium aurelia. The $A$. aerogenes was obtained from Dr J. F. Wilkinson, Dept. of Bacteriology, University of Edinburgh. The macronuclei were isolated as described by Stevenson (1967c). DNA was also prepared from isolated $\mu$ particles.

To prepare DNA from Micrococcus lysodeikticus, Io g. dried bacteria were suspended in $45 \mathrm{ml}$. of $0.15 \mathrm{M}-\mathrm{NaCl}+0.15 \mathrm{M}$-sodium citrate (SSC) by stirring for $4 \mathrm{hr}$ at $4^{\circ}$. The suspended bacteria were treated with lysozyme (EC 3.2. I. I7; $0.1 \mathrm{mg} . / \mathrm{ml}$. Sigma) at $37^{\circ}$ until lysis occurred (a great increase in viscosity), then sodium dodecyl sulphate (SDS) was added to a final concentration of $0.3 \%$, and this mixture was kept at $60^{\circ}$ for $10 \mathrm{~min}$. After cooling, Pronase (Calbiochem) was added to $0.2 \mathrm{mg} . / \mathrm{ml}$., and the mixture incubated at $37^{\circ}$ overnight. The Pronase was self-digested for $2 \mathrm{hr}$ before use. The digest was deproteinized with $9+\mathrm{I}, \mathrm{v} / \mathrm{v}$, chloroform + octanol mixture and the procedure of Marmur (196I) followed. The final preparation was stored in the refrigerator over chloroform.

DNA was prepared from exponential phase Aerobacter aerogenes A 3(0). Bacteria were grown in a glucose + salts medium to an extinction at $650 \mathrm{~m} \mu$ of $\mathrm{I} \cdot 0$, harvested by centrifugation at $7,000 \mathrm{~g}$ for $10 \mathrm{~min}$. at $3^{\circ}$, washed once with $0.15 \mathrm{M}-\mathrm{NaCl}+0.0 \mathrm{I} \mathrm{M}$ EDTA (pH 8.0) and centrifuged down. DNA was prepared by the method of Marmur (I96I) and stored as before.

Isolated macronuclei of Paramecium aurelia were resuspended in SSC to a volume equal to that of the original packed paramecia from which they were prepared, and SDS was added to $0.1 \%$. The lysate was kept at $65^{\circ}$ for $20 \mathrm{~min}$., allowed to cool and then Pronase was added to $0.1 \mathrm{mg}$. $/ \mathrm{ml}$. After overnight digestion at $37^{\circ}$ the extract was deproteinized three times with $9+\mathrm{I}(\mathrm{v} / \mathrm{v})$ chloroform + octanol mixture. This final extract was then subjected to a $\mathrm{CsCl}$ gradient centrifugation.

Pronase digestion followed by deproteinization was unsatisfactory for the preparation of DNA from $\mu$ particles. It was found better to suspend the isolated particles in $\mathrm{I} .5 \mathrm{ml}$. of $4 \times \mathrm{SSC}$ and freeze at $-20^{\circ}$. After thawing, $0.5 \mathrm{ml}$. of $10 \% \mathrm{SDS}$ was added, followed by treatment at $65^{\circ}$ for $20 \mathrm{~min}$. After cooling, the volume was made to $3 \mathrm{ml}$. with $4 \times \mathrm{SSC}$, and a $\mathrm{CsCl}$ gradient was carried out. $\mathrm{CsCl}$ for use in gradients was purified by precipitation with ethanol and washing with ether. Background absorption at $260 \mathrm{~m} \mu$ was 0.02 or less at the concentration used.

To run gradients, $3.40 \mathrm{~g}$. of $\mathrm{CsCl}$ were dissolved in $2.5 \mathrm{ml}$. of the DNA preparation and this solution poured into a 5- $\mathrm{ml}$. thin-walled polypropylene tube, and $\mathrm{I} \mathrm{ml}$. of liquid paraffin was overlaid. The $3 \times 5 \mathrm{ml}$. swing-out rotor of the MSE 'Superspeed $50^{\text {' }}$ ultracentrifuge was used, centrifugation being for 65 to $75 \mathrm{hr}$ at $32,000 \mathrm{rev}$./min. at 18 to $20^{\circ}$. The rotor was allowed to coast to a stop, and gradients were fractionated by collecting drops. To each fraction was added 0.8 or $1.0 \mathrm{ml}$. of SSC, and the extinction at $260 \mathrm{~m} \mu$ was read in a Beckman DB spectrophotometer, with $0.5 \mathrm{~cm}$. light-path optical cells. Sometimes gradient fractions were assayed for DNA content by the diphenylamine method (Burton, 1956). Material to be run in a gradient was always assayed by this method to determine the amount of DNA present. Tm was determined as described by Marmur \& Doty (1959) but a Beckman DB spectrophotometer was used 


\title{
Assay for ribonucleoside triphosphate incorporation
}

The assay mixture was similar to that of Weiss (1960) except that either $\left(8-{ }^{14} \mathrm{C}\right)$ ATP or $\left(4^{-14} \mathrm{C}\right)$ UTP (from the Radiochemical Centre, Amersham, Bucks., England) or GTP. ${ }^{3}$ H (obtained from Schwarz Bioresearch Inc., Orangeburg, New York, U.S.A.) were the radioactive triphosphates used in the assay. Incubation, precipitation, sample preparation and counting procedures followed those described earlier (Stevenson, 1967c).

\section{RESULTS}

\section{General observations on isolated $\mu$ particles}

The preparations obtained from Paramecium aurelia stock 540 bearing $\mu$ particles consisted of at least $90 \%$ of rod-shaped particles 2 to $5 \mu$ long $\times 0.5 \mu$ wide. Such particles were not obtained in preparations from paramecia not bearing $\mu$ particles. Phase-contrast microscopy showed the presence of contaminating cell debris in $\mu$ particle preparations; but this debris was the only material obtained in preparations from the paramecia not bearing $\mu$ particles. Electron microscopy of the $\mu$ particle preparations showed that the principal contaminants were cilia and fragments of cilia, some mitochondria and other small debris (Pl. I, fig. I). The appearance of the isolated $\mu$ particle compares well with the appearance found by Beale \& Jurand (1960, I966), but the capsule reported by these authors was not observed. The presence of this component appeared to be variable. Other electron micrographs showed $\mu$ particles which had a median constriction; these may have been in the course of division.

\section{Table I. Contamination of $\mu$ particle and control preparations with viable Aerobacter aerogenes $A 3(0)$}

\begin{abstract}
The left-hand column is a total count of particles of all kinds in a preparation, i.e. $\mu$ particles, mitochondria, Aerobacter aerogenes and others. Each preparation was made to $10 \mathrm{ml}$. before the haemocytometer count, and all preparations were made from paramecia which had been grown in 501 . culture medium. The three upper lines refer to experiments with paramecia of Paramecium aurelia stock 540 bearing $\mu$ particles; the fourth line is a control experiment made with $P$. aurelia stock 513 (sensitive paramecia). Suspensions were serially diluted to $10^{-4}$, and $0.1 \mathrm{ml}$. was plated in triplicate on to nutrient agar plates, and the mean number of bacterial colonies after $60 \mathrm{hr}$ of incubation at $35^{\circ}$ taken. Shorter incubation periods did not show the true extent of the bacterial contamination.
\end{abstract}

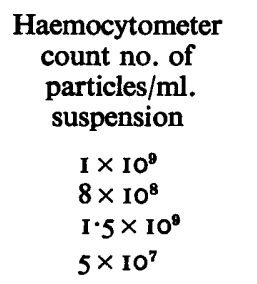

$\begin{array}{ccc}\begin{array}{c}\text { Dilution for } \\ \text { plating }\end{array} & \begin{array}{c}\text { No. bacterial } \\ \text { colonies/ml. } \\ \text { after } 60 \mathrm{hr} \text { at } \\ 35^{\circ} \text { (mean) }\end{array} & \begin{array}{c}\text { Viable } \text { A. aero- } \\ \text { genes as \% of } \\ \text { total particles }\end{array} \\ 10^{-4} & 130 & 0.130 \\ 10^{-4} & 165 & 0.206 \\ 10^{-4} & 610 & 0.406 \\ 10^{-4} & 1310 & 26 \cdot 2\end{array}$

Plate I, fig. 2, is a higher-power electron micrograph of a single $\mu$ particle. This shows the outer double membrane very clearly and also shows the lack of differentiation of the internal contents. The granular material in the cytoplasm is poorly defined, and no conclusion can be drawn about its nature. The resemblance to a bacterium is, however, very striking.

Tests for contamination with the food bacterium Aerobacter aerogenes A3(0) were 
made by dilution and plating of $\mu$-particle suspensions on nutrient agar plates and also by testing the suspensions with antiserum specific against the $A$. aerogenes A $3(0)$, which is a rough strain of stable serotype. Table $I$ shows typical results for the viable bacterial counts of $\mu$ particle preparations and preparations from paramecia not bearing $\mu$ particles. The results show the approximate upper and lower degrees of contamination. It is evident that, while the number of viable $A$. aerogenes was similar in both preparations, this number as a percentage of the total number of rod-shaped particles was much lower in a $\mu$-particle preparation than in a preparation from paramecia not bearing $\mu$ particles, there being at least a 50-fold difference between the former proportion and the latter.

Table 2 shows the results of agglutination tests on the $\mu$ particle suspensions with rabbit antiserum prepared against the Aerobacter aerogenes A 3(0). It is clear that the $\mu$ particles were not at all agglutinated by this antiserum, which had a titre of $1 / 640$ against $A$. aerogenes A 3(0). This result would be expected if the contamination with $A$. aerogenes A $3(0)$ was as low as that found in the plate counts, and shows that the $\mu$ particles. were not serologically like the food bacteria.

\title{
Table 2. Contamination of $\mu$ preparations with Aerobacter aerogenes $A 3(0)$ agglutination of preparations with anti-A3(O) serum
}

\begin{abstract}
A. Aerogenes A3 (o) was grown up overnight in nutrient broth at $37^{\circ}$, the culture centrifuged, and the deposit washed twice with distilled water. The deposit was taken up in Dryl solution and this suspension adjusted to an extinction scale reading of $1 \cdot 3$ at $650 \mathrm{~m} \mu$ in a Beckman DB spectrophotometer. The $\mu$ suspension, prepared and washed as described, was adjusted to a similar extinction scale reading, also in Dryl solution. Suspension $(0.2 \mathrm{ml}$.) was mixed with $0.2 \mathrm{ml}$ diluted antiserum (Dryl solution as diluent) in agglutination tubes, and incubated overnight in a water bath at $37^{\circ}$. Agglutination was then scored on a scale up to $3+$. For the experiments here, the antiserum had a titre of $1 / 640$.
\end{abstract}

\begin{tabular}{lcc}
\multicolumn{1}{c}{ Preparation } & Dilution of serum & $\begin{array}{c}\text { Agglutination of } \\
\text { suspension }\end{array}$ \\
$\mu$ particles & I/40 & -- \\
$\mu$ particles & I/80 & -- \\
$\mu$ particles & I/160 & ---- \\
$\mu$ particles & No serum & ---- \\
A. aerogenes A 3(0) & I/40 & +++ \\
$A$. aerogenes A 3(0) & I/80 & +++ \\
A. aerogenes A 3(0) & I/160 & ++ \\
A. aerogenes A 3(0) & No serum & ---- \\
No bacteria & I/40 & -----
\end{tabular}

\section{Chemical composition of isolated $\mu$ particles}

Both $\mu$-particle preparations and preparations from paramecia not bearing $\mu$ particles were analysed by the methods described. Table 3 gives the results obtained, in terms of $\mu \mathrm{g}$. component $/ \mathrm{mg}$. dry weight of preparation. The yields, in terms of dry weight, were very different for $\mu$-particle preparations and for preparations from sensitive paramecia. The yield of $\mu$ particles was about I mg. dry weight from 20 to $25 \mathrm{mg}$. dry weight paramecia; the yield of preparations from paramecia not bearing $\mu$ particles was about $\mathrm{I} \mathrm{mg}$. dry weight from about $500 \mathrm{mg}$. dry weight of paramecia. Since $\mu$-particle preparations therefore contained about 20 times as much material as preparations from sensitive paramecia, from a similar amount of starting material, this suggests that $95 \%$ of the $\mu$-particle preparations did in fact consist of $\mu$ particles, a 
degree of purity in agreement with that found from observations by light and electron microscopy. However, the data in Table 3 also suggest that the method of Lowry et al. (I95I) for the estimation of protein gave an overestimate. It seems possible that this result was due to the presence of some component in the extracts used for the analysis which caused intensification of the colour obtained. All reagents gave blank reactions, and since both $\mu$-particle and sensitive-paramecium preparations showed this effect, it seems that it must have arisen from the presence of some contaminating material. It is evident that there were distinct differences between preparations of $\mu$ particles and preparations from sensitive paramecia, particularly in DNA and RNA content. The $\mu$ particles contained DNA, RNA, protein and perhaps carbohydrate and lipid.

\section{Table 3. Chemical composition of isolated $\mu$ particles of Paramecium aurelia 540 and of isolated control preparations}

\begin{tabular}{|c|c|c|c|c|c|}
\hline Preparation & DNA & RNA & Protein & Carbohydrate & Lipid \\
\hline particles & $\begin{array}{l}5 I \cdot 4 \\
( \pm 9 \cdot I) \\
(I \cdot 028)\end{array}$ & $\begin{array}{l}96 \cdot 0 \\
( \pm 16 \cdot 8) \\
(I \cdot 92)\end{array}$ & $\begin{array}{l}1035 \\
( \pm 242) \\
(20 \cdot 70)\end{array}$ & $\begin{array}{l}45.9 \\
( \pm 9.7) \\
(0.918)\end{array}$ & $\begin{array}{l}\text { I I.3 } \\
( \pm 2 \cdot 0) \\
(0.226)\end{array}$ \\
\hline Control (540 sensitive) & $\begin{array}{l}\text { II } \cdot 8 \\
( \pm 6 \cdot I)\end{array}$ & $\begin{array}{l}53 \cdot 8 \\
( \pm 9 \cdot 3)\end{array}$ & $\begin{array}{l}1064 \\
( \pm I 62)\end{array}$ & $\begin{array}{l}57 \cdot 5 \\
( \pm 3 \cdot 7)\end{array}$ & Not tested \\
\hline
\end{tabular}

\section{The DNA of the $\mu$ particles}

DNA from Paramecium aurelia 540 was first characterized by density-gradient centrifugation in $\mathrm{CsCl}$ and the determination of the temperature of melting, Tm. For this DNA was prepared from isolated macronuclei of $P$. aurelia 540. This was used for two reasons: (i) it was found that DNA was difficult to purify from whole $P$. aurelia, owing to a high degree of nuclease activity in the extracts, resulting in degraded DNA; (ii) the use of DNA prepared from $P$. aurelia macronuclei avoided the possibility of contamination of the DNA with that from any residual Aerobacter aerogenes, and resulted in fewer manipulations being necessary to purify the DNA. Macronuclei were isolated as described by Stevenson (1967c).

The buoyant density of macronuclear DNA was estimated to be I.693 g./c.c. (Fig. I a). Densities were estimated by reference to marker DNA of Micrococcus lysodeikticus and Aerobacter aerogenes A 3(0); these have densities of I.73I g./c.c. and I.7I 5 g./c.c., respectively (Schildkraut, Marmur \& Doty, I962). A density of I.693 g./ c.c. corresponds to a guanine + cytosine (GC) content of $32 \mathrm{~mole} \%$. Heating the DNA solution at $100^{\circ}$ for $5 \mathrm{~min}$., then fast-cooling in an ice-bath, resulted in an increase of the buoyant density to $\mathrm{I} \cdot 706 \mathrm{~g}$./c.c. (Fig. I $b$ ). The pattern of change of extinction with temperature was as expected for a double-stranded DNA (Fig. Ic) and $\mathrm{Tm}=8 \mathrm{I} \cdot 8^{\circ}$, 
corresponding to GC content of $30.6 \mathrm{~mole} \%$. These values are substantially in agreement, and are also in agreement with the values given by Smith-Sonneborn, Green \& Marmur (1963), Gibson (1965) and Suyama \& Preer (1965).

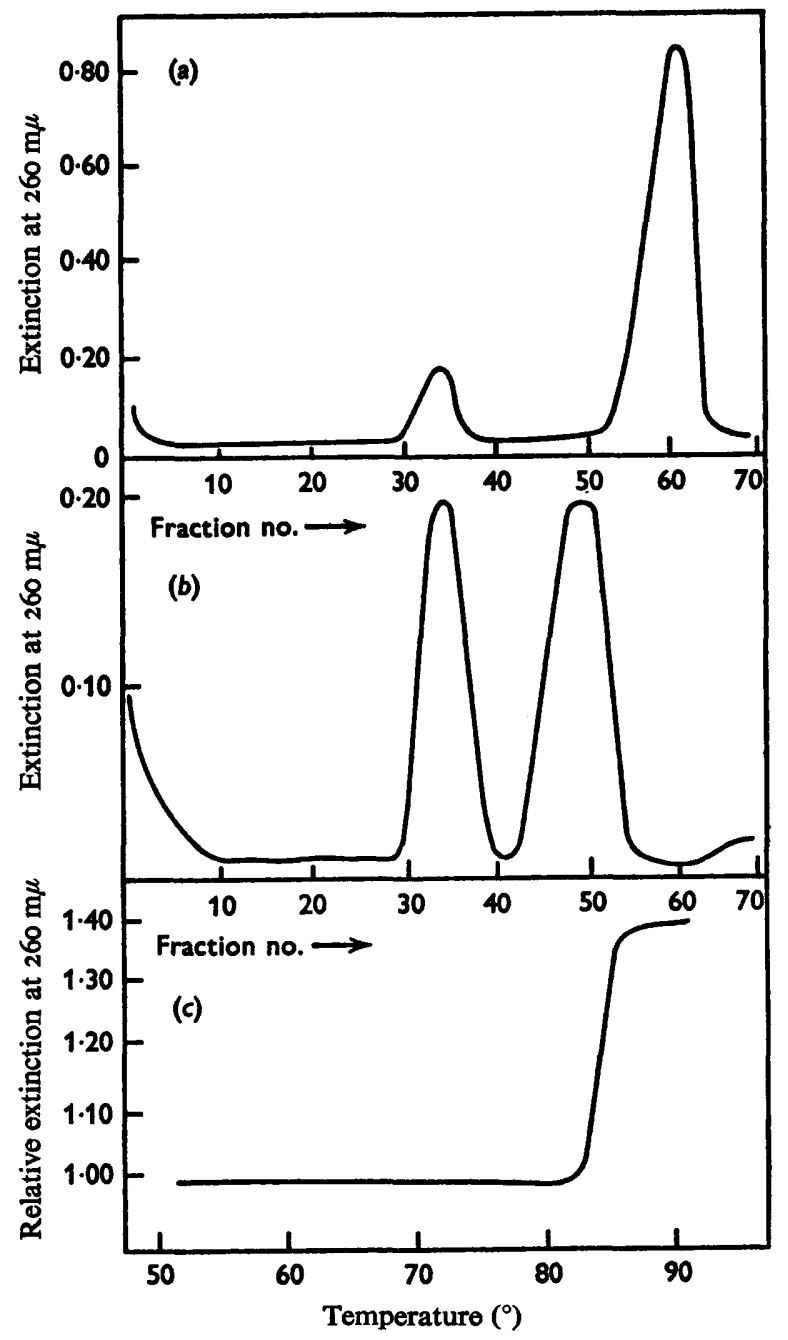

Fig. I. (a) $\mathrm{CsCl}$ density gradient of native DNA of Paramecium aurelia 540, prepared from isolated macronuclei, with marker of Micrococcus lysodeikticus DNA, $210 \mu \mathrm{g}$., of $P$. aurelia DNA, $58 \mu \mathrm{g}$., of $M$. lysodeikticus DNA, $70 \mathrm{hr}$ at $32,000 \mathrm{rev} . / \mathrm{min}$. $(100,000 \mathrm{~g})$ at $19^{\circ}$. (b) As figure (a), but $6 \mathrm{I} \mu \mathrm{g}$. heat-denatured DNA of $P$. aurelia 540 substituted for native DNA. (c) Melting curve of $P$. aurelia 540 macronuclear DNA. Buffer: SSC. Tm $=81 \cdot 8^{\circ}$.

Preparation of DNA from $\mu$ particles by the Pronase method or by the method of Marmur (1961) was not found feasible, but $2.5 \%$ SDS lysates gave satisfactory results in $\mathrm{CsCl}$ gradients. Figure 2 shows the result of density-gradient centrifugation of a $\mu$ particle lysate. The peak had a buoyant density estimated to be I·694 g./c.c. Preparations from paramecia lacking $\mu$ particles and treated in the same way showed no 
such peak (Fig. 3). Thus $\mu$ particles contained DNA capable of forming a peak in a $\mathrm{CsCl}$ gradient; preparations from sensitive paramecia did not. To test whether the DNA in the $\mu$-particle preparations did in fact have this density, a mixing experiment in which DNA of macronuclei Paramecium aurelia 540 was added to a $\mu$-particle lysate and the mixture subjected to density-gradient centrifugation; Fig. $4 a$ shows the results. The use of a lysate did not appear to affect the results obtained; from the size of the peak the two DNA's must have mixed, and must have been very similar in density. Figure $4 a$ also shows the results of analyses on gradient fractions by using the diphenylamine method for DNA estimation. It is evident that this method gave similar results to those by the measurement of extinction at $260 \mathrm{~m} \mu$.

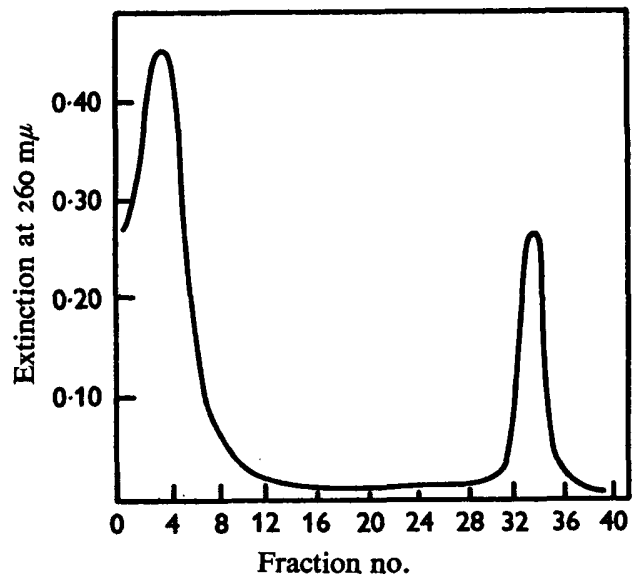

Fig. 2

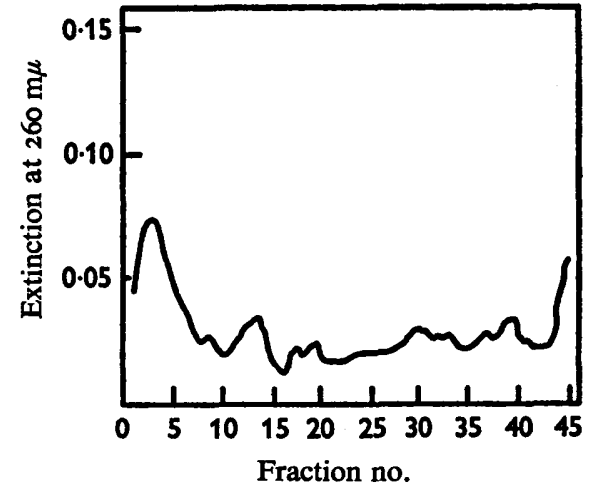

Fig. 3

Fig. 2. $\mathrm{CsCl}$ density gradient of $2.5 \%$ SDS lysate of $\mu$ particles of Paramecium aurelia stock 540. No marker DNA added to this lysate, which contained $91 \mu \mathrm{g}$. DNA; $67 \mathrm{hr}$ at 32,000 rev./min. $(100,000 \times g)$ at $19^{\circ}$.

Fig. 3. $\mathrm{CsCl}$ density gradient of $2.5 \%$ SDS lysate of control preparation from Paramecium aurelia stock 540 (sensitive paramecia). No marker DNA added; $22 \mu \mathrm{g}$. of diphenylaminereacting material in lysate; $69 \mathrm{hr}$ at $32,000 \mathrm{rev} . / \mathrm{min} .(100,000 \times \mathrm{g})$ at $19^{\circ}$.

Figure $4 b$ shows the temperature/extinction profile for DNA from $\mu$-particle preparations. The Tm had a mean value, based on several determinations with three different samples, of $82.0^{\circ}$. This led to a value for the GC content of $31 \cdot 0 \mathrm{~mole} \%$, substantially in agreement with the value from density-gradient centrifugation, which was $32 \cdot 3$ mole $\%$.

In further experiments $\mu$ particles were treated with deoxyribonuclease (EC 3. I $_{4} 4$. 5) before lysis, to test whether the DNA found in $\mu$-particle preparations was outside the particles as a contaminant, or inside and perhaps protected from enzyme action by the wall of the $\mu$ particle. Figure 5 shows the result of such an experiment; the legend gives the conditions used. Under these conditions DNA of Paramecium aurelia 540 was degraded, and did not give a peak in a $\mathrm{CsCl}$ gradient. Since the DNA in $\mu$-particle preparations was not degraded, it seems that it must have been protected from nuclease action, presumably by the outer membrane of the $\mu$ particle.

The material banding in $\mathrm{CsCl}$ gradients was established as DNA on the basis of the 
following criteria: (i) peak material was examined for a typical nucleic acid spectrum, which it was always found to possess; (ii) DNA preparations gave typical temperature/ extinction curves, and an increase of buoyant density of about $0.015 \mathrm{~g}$./c.c. occurred on heating to $100^{\circ}$ and cooling in ice; (iii) peak material gave a typical reaction with diphenylamine; (iv) the ability to band in $\mathrm{CsCl}$ was abolished by treatment with DNase. These are properties which native double-stranded DNA would be expected to possess.

In summary, therefore, the principal findings are that the $\mu$ particles possessed DNA, presumably inside the $\mu$ particle protected by a membrane. The buoyant density of this DNA, and its Tm, suggest that its base composition is similar to that of the macronuclear DNA of Paramecium aurelia 540.

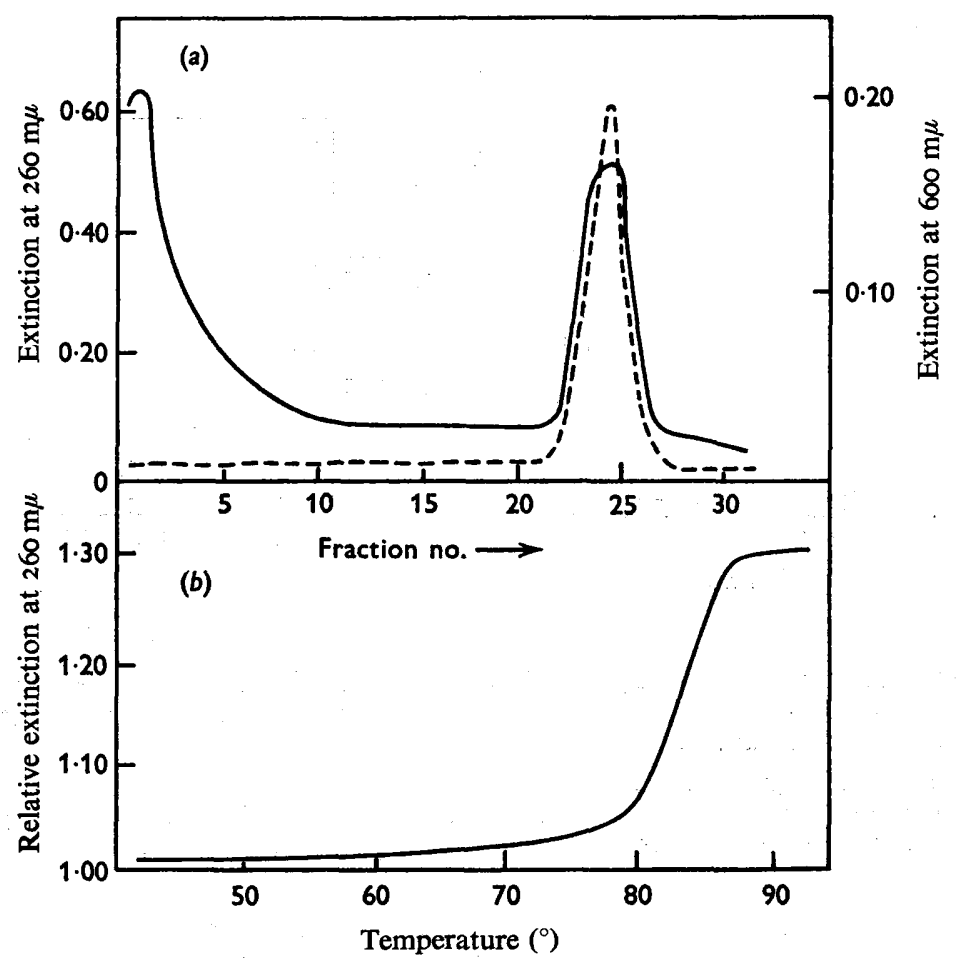

Fig. $4(a) . \mathrm{CsCl}$ density gradient of $\mu$ particles $2.5 \%$ SDS lysate + DNA of Paramecium aurelia 540 macronuclei. The lysate contained $102 \mu \mathrm{g}$. DNA and $79 \mu \mathrm{g}$. $P$. aurelia macronuclear DNA. Recovery of DNA in peak = about I35 $\mu \mathrm{g}$., i.e. more than either component, indicating that the two components have a similar density. - Extinction at $260 \mathrm{~m} \mu$; --- , extinction at $600 \mathrm{~m} \mu$ in the diphenylamine reaction; $70 \mathrm{hr}$ at $32,000 \mathrm{rev} . / \mathrm{min}$. (100,000 g) at $19^{\circ}$. (b) Melting curve of DNA from isolated $\mu$ particles of $P$. aurelia 540. Buffer: SSC. $\mathrm{Tm}=82^{\circ}$.

\section{Ribonucleoside triphosphate incorporation by $\mu$ particles of Paramecium aurelia 540}

Experiments were made to test whether the $\mu$ particles possessed a mechanism for RNA synthesis, by assaying the incorporation by $\mu$ particles of radioactive nucleoside triphosphates into acid-insoluble material. Experiments were also made with control preparations from paramecia not bearing $\mu$ particles. 
Table 4 gives typical results on the incorporation of ${ }^{14} \mathrm{C}-\mathrm{ATP}$ and ${ }^{3} \mathrm{H}-\mathrm{GTP}$ into acid-insoluble material by isolated $\mu$ particles lysed by three cycles of freezing and thawing, and on the incorporation of ${ }^{14} \mathrm{C}$-ATP by similarly treated preparations from sensitive paramecia. All results are pmoles of labelled triphosphate incorporated into acid-insoluble material in $15 \mathrm{~min}$. at $30^{\circ}$. The various additions to and omissions from the assay mixture are detailed in the legend to Table 4. Incorporation of UTP was very similar to that of ATP $(56 \mathrm{I} \cdot 3$ pmoles with the complete mix), but these results are not presented in detail because only one series of experiments with this compound was made. All other experiments had at least four replications. Table 4 shows that the $\mu$ particles had a very active nucleoside triphosphate incorporating activity. Preparations from sensitive paramecia always gave negative results, there being no incorporation in any of seven replications of this experiment. This suggests that the incorporation was indeed due to the $\mu$ particles.

Table 4. Ribonucleoside triphosphate incorporation by isolated $\mu$ particles and control preparations from Paramecium aurelia 540 and 540 (sensitive)

All figures are $\mu \mu$ mole triphosphate incorporated into acid-insoluble material in $15 \mathrm{~min}$. at $30 \% \mathrm{mg}$. protein in the experimental extract.

\begin{tabular}{|c|c|c|c|c|c|}
\hline \multirow[b]{2}{*}{$\begin{array}{l}\text { Additions/omissions } \\
\text { to assay mixture }\end{array}$} & \multicolumn{4}{|c|}{$\mu$ particles } & \multirow{2}{*}{$\overbrace{\begin{array}{c}{ }^{14} \mathrm{C}-\mathrm{ATP} \\
\text { pmole }\end{array}}^{\text {Control }}$} \\
\hline & $\begin{array}{c}{ }^{14} \mathrm{C}-\mathrm{ATP} \\
\text { pmole }\end{array}$ & Inhibition (\%) & $\begin{array}{c}{ }^{3} \mathrm{H}-\mathrm{GTP}- \\
\mu \mu \mathrm{mole}\end{array}$ & Inhibition (\%) & \\
\hline $\begin{array}{l}\text { None (complete } \\
\text { system) }\end{array}$ & $595 \cdot 7$ & 0.0 & $367 \cdot 5$ & 0.0 & 0 \\
\hline No ATP & - & - & $72 \cdot 9$ & $80 \cdot 2$ & - \\
\hline No GTP & $77 \cdot 8$ & $86 \cdot 9$ & - & - & 0 \\
\hline No CTP & $230 \cdot 0$ & $61 \cdot 4$ & $31 \cdot 9$ & $91 \cdot 3$ & 0 \\
\hline No UTP & $287 \cdot 1$ & $5 \mathrm{I} \cdot 8$ & $109 \cdot 6$ & $70 \cdot 2$ & 0 \\
\hline No triphosphates & $180 \cdot 2$ & $69 \cdot 7$ & $81 \cdot 9$ & $77 \cdot 7$ & 0 \\
\hline + Actinomycin $\mathrm{D}^{*}$ & $260 \cdot 2$ & $56 \cdot 3$ & $59 \cdot 0$ & 83.9 & 0 \\
\hline + Ribonuclease $\dagger$ & $42 \cdot 3$ & $92 \cdot 9$ & - & - & 0 \\
\hline No $\mathrm{Mg}^{2+}$ & 0.0 & 100 & - & - & 0 \\
\hline
\end{tabular}

* Concentration of Actinomycin D was $15 \mu \mathrm{g} . / \mathrm{ml}$. Actinomycin D was a gift from Merck, Sharp and Dohme, Inc., Rahway, N.J., U.S.A.

$\dagger$ Concentration of ribonuclease was $25 \mu \mathrm{g} . / \mathrm{ml}$.

Control preparations gave negative results in every experiment (seven replicates).

For optimal activity the system required all four triphosphates and the presence of $\mathrm{Mg}^{2+}$ ions, the optimal concentration of these being $5 \mathrm{mM}$. The system was susceptible to actinomycin D, known to inhibit DNA-dependent RNA synthesis, and an RNAasesensitive product was synthesized. The optimum $\mathrm{pH}$ value was not sharp, and lay in the range $\mathrm{pH} 8 \cdot \mathrm{I}$ to $9 \cdot 0$; incorporation decreased sharply at $\mathrm{pH}$ values outside this range. This range was found by Weiss (1960; 1962) to be optimal for DNA-dependent RNA synthesis. The findings thus suggest that RNA is synthesized in a DNAdependent reaction by the $\mu$ particles.

Figure 6 shows the time-course of incorporation of ${ }^{14} \mathrm{C}$-ATP. Incorporation normally ceased after 15 to $20 \mathrm{~min}$., but on occasion continued to 25 to $30 \mathrm{~min}$. ${ }^{14} \mathrm{C}$-UTP and ${ }^{3} \mathrm{H}-$ GTP gave similar time-courses. Loss of TCA-insoluble label occurred to $60 \mathrm{~min}$.; after this time over half the label incorporated in $15 \mathrm{~min}$. had been lost. That there was no increase of TCA-insoluble label on prolonging the incubation suggests that there was little bacterial contamination, but that degradative processes were occurring. 
From experiment to experiment variation in the amount of inhibition was observed when one or more nucleoside triphosphates was absent from the assay mixture; this may have reflected variations in the amount of nucleoside triphosphate present in the $\mu$ particles, or there may have been differences in the isolation procedures which caused this. This variation was not more than $\pm 15 \%$. Activity was retained after storage up to $I$ month in the frozen state (longer periods not tested). When a $\mu$-particle preparation was more contaminated with cell debris than usual, the preparation had a markedly lower incorporating activity.

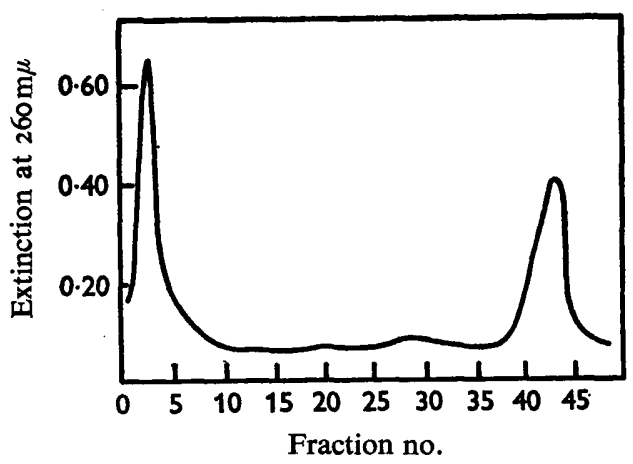

Fig. 5

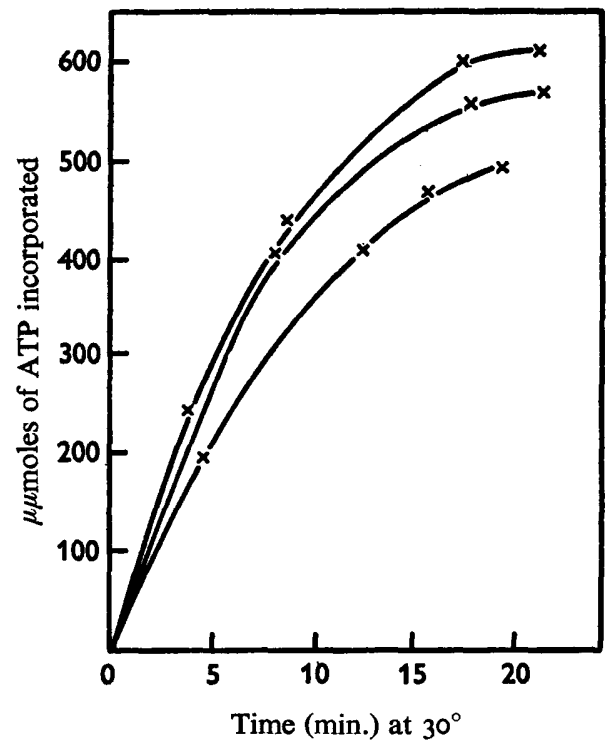

Fig. 6

Fig. 5. CsCl density gradient of $2.5 \%$ SDS lysate of $\mu$ particles of $P$. aurelia 540 which was treated with DNase Io $\mu \mathrm{g}$. $/ \mathrm{ml}$. before lysis. DNase treatment was for $45 \mathrm{~min}$. at $37^{\circ}$; no marker DNA was added after lysis; the lysate contained $38 \mu \mathrm{g}$. DNA; $68 \mathrm{hr}$ at $32,000 \mathrm{rev}$./ min. $(100,000 \times g)$ at $18^{\circ}$.

Fig. 6. Time-course of incorporation of $8-{ }^{14} \mathrm{C}$-ATP by isolated $\mu$ particles of $P$. aurelia 540. Conditions as described in text. Three experiments with separate preparations are shown.

\section{DISCUSSION}

From the results presented in this paper it seems more firmly established that the $\mu$ particle is indeed a symbiotic bacterium. It resembles a bacterium in size, shape and appearance in the electron microscope. The chemical composition, the presence of DNA and RNA, and the ability to synthesize RNA are compatible with this hypothesis. In their appearance in the electron microscope, $\mu$ particles resemble Gramnegative bacteria. Nuclear bodies, as observed in many species, are not evident in the isolated $\mu$ particle. Beale \& Jurand (1960) concluded that the DNA was spread throughout the interior of the particle and also stated (Beale \& Jurand, 1966) that fine filaments resembling DNA may be observed in the interior of the particle. This is not evident in PI. $x$, fig. 2, but there may be changes during isolation which might account for this. If the DNA of the particle was not localized then it would not show up as a distinct 
region. Sonneborn (1959) suggested that this might also be the case for the kappa particle.

The cell wall of the $\mu$ particle shows great resemblance in fine structure to the cell walls of other bacteria. The resemblance is closest to a Gram-negative bacterium, and it is of interest that $\mu$ particles have a negative Gram-reaction, and they are not acidfast. It has been shown (Stevenson, 1967a) that the $\mu$ particle contains $\alpha, \epsilon$-diaminopimelic acid, presumably as a constituent of the cell wall.

As an endosymbiotic bacterium, the $\mu$ particle must have at some time invaded the Paramecium cytoplasm, presumably via the buccal cavity. There is no evidence that the comparatively rigid and highly complex cell wall of Paramecium is capable of undergoing any process comparable to pinocytosis, though this process occurs in the food vacuoles. There seems little chance of infection through the cytopyge, as the opening there is small and short-lived at the discharge of old food vacuoles, and any flow is outward. Jurand (196I) showed this in an electron microscope study, and also observed that breakage of a food vacuole before discharge must be a rare event. This makes it difficult to postulate an infection route. But Beale \& Jurand (1966) observed that many wild stocks of Paramecium aurelia contain endosymbiotes, though these are frequently lost on culture in the laboratory. This would suggest that endosymbiosis is a flexible condition, established and lost with change of the cell's environment, which suggests that infection must be common. Infection of cells with symbiotes has been achieved with several particles, but not with the $\mu$ particle, though this may be because the correct conditions have not been found.

The mate-killing effect of the $\mu$ particle is in itself rather perplexing, as it results in the death of half the exconjugant animals from any one cross. Siegel (1954) showed that in syngen 8 mate-killers, physical contact of the mate-killer and sensitive animals was necessary, and that the main killing action was due to interference with the prezygotic macronucleus, possibly at the level of nucleic acid metabolism. Gibson \& Beale (1962) showed that in stock 540 complete conjugation with the exchange of genes was necessary for killing action. However, a fruitful approach to this problem is difficult to devise.

The results presented in this paper have shown that the $\mu$ particle of Paramecium aurelia stock 540 possesses some of the attributes of an organism. It possesses DNA, is able to direct the synthesis of RNA, shows comparable ultrastructure to a free-living bacterium; in fact has characteristics of a free-living cell. But so far it has only been found to have a habitat in the Paramecium cytoplasm. In this respect, therefore, it is comparable to a cell organelle. However, where the $\mu$ particle differs from organelles such as the chloroplast and mitochondrion is that it lacks their specialization of function, for since the Paramecium can survive and develop normally without the $\mu$ particle, it cannot have any essential function. However, it may be able to carry out synthetic functions that the host cell cannot, as the lambda particle of stock 299 (syngen 4) is able to do (Soldo, I963). Kung (I966) has shown that the kappa particle of stock 5I can respire and utilize glucose in vitro. Thus it would seem that all these particles possess considerable metabolic ability. This would seem very likely if the endosymbiotic particles of Paramecium are indeed taken up and lost with comparative frequency, for then the endosymbiotes would be bacteria which could live in the same habitat as Paramecium in the wild. It seems simplest, therefore, to regard these particles as bacteria capable of living endosymbiotically and possibly giving benefit to the host 
cell, which in at least some cases has evolved mechanisms in its genes (in the case of stock 540, the $\mathrm{M}$ genes) for assisting in the maintenance of this state. Clearly, this process may be regarded as a stage toward an obligate intracellular existence for the particle, a stage in the evolution of an organelle carrying out functions indispensable to the host cell.

I should like to thank Professor G. H. Beale, F.R.S., for his frequent advice and criticism, Mr R. Sinden for carrying out the electron microscopy, Miss A. Wightman for help with the cultivation of the paramecia, and others who have offered suggestions, advice and criticism.

The work was done during the tenure of a Medical Research Council postgraduate studentship, and forms part of a thesis submitted for the degree of Ph.D. at the University of Edinburgh.

\section{REFERENCES}

Anderson, J. F., Preer, J. R., Jun., Preer, L. B. \& Bray, M. (1964). Studies on killer particles from Paramecium; structure of refractile bodies of K particles. J. Microscopie 3, 395.

Beale, G. H. \& JuRAND, A. (1960). Structure of the matekiller $(\mu)$ particles of Paramecium aurelia stock 540. J. gen. Microbiol. 23, 243.

Beale, G. H. \& JuRAND, A. (1966). Three different types of matekiller $(\mu)$ particles in Paramecium aurelia (syngen I). J. Cell Sci. 1, 31 .

BLOOR, W. R. (1947). A colorimetric procedure for the determination of small amounts of fatty acid. J. biol. Chem. 170, 671.

BURTON, K. (1956). A study of the conditions and mechanism of the diphenylamine reaction for the colorimetric estimation of deoxyribonucleic acid. Biochem. J. 62, 315.

DRYL, S. (1959). Antigenic transformation in Paramecium aurelia after homologous antiserum treatment during autogamy and conjugation. J. Protozool. 6, suppl. 25.

Gibson, I. (1965). Electrophoresis of extracts of Paramecium aurelia containing metagons. Proc. $R$. Soc. B 161, 538.

Gibson, I. \& Beale, G. H. (1962). The mechanism whereby the genes $M_{1}$ and $M_{2}$ in Paramecium aurelia stock 540 control the growth of the mate-killer (mu) particles. Genet. Res. 3, 24.

JoNES, I. G. (1965). Studies of the characterisation and structure of the immobilisation antigens of Paramecium aurelia. Biochem. J. 96, 17.

JuRAnd, A. (I96I). An electron microscope study of food vacuoles in Paramecium aurelia. J. Protozool. 8, 125.

Kellenberger, E., RYTER, A. \& Séchaud, J. (1958). Electron microscope study of DNA containing plasms. II. Vegetative and mature phage DNA as compared with normal bacterial nucleoids in different physiological states. J. biophys. biochem. Cytol. 4, 67I.

Kung, C. (1966). Aerobic respiration of kappa particles in Paramecium aurelia stock 5I. J. Protozool. 13, suppl. 1 I.

Lowry, O. H., Rosebrough, N. J., Farr, A. L. \& Randall, R. J. (195I). Protein measurement with the Folin phenol reagent. J. biol. Chem. 193, 265.

MARMUR, J. (1961). A procedure for the isolation of DNA from micro-organisms. J. molec. Biol. 3, 208.

MARMUR, J. \& DotY, P. (1959). Heterogeneity in DNA's. I. Dependence on composition of the configurational stability of DNA's. Nature, Lond. 183, 1427.

Mueller, J. A. (1962). Induced physiological and morphological changes in the $B$ particle and $R$ body of killer paramecia. J. Protozool. 9, suppl. 26.

OGUR, M. \& Rosen, G. (1950). The nucleic acids of plant tissues. I. The extraction and estimation of deoxypentose nucleic acid and pentose nucleic acid. Archs Biochem. Biophys. 25, 262.

Preer, J. R., Jun., Hufnagel, L. A. \& Preer, L. B. (I966). Structure and behaviour of R bodies from killer paramecia. J. Ultrastruct. Res. 15, I3I.

REYNolds, E. S. (1963). The use of lead citrate at high pH as an electron-opaque stain in electron microscopy. J. Cell Biol. 17, 208. 

Journal of General Microbiology, Vol. 57, No. I

Plate I

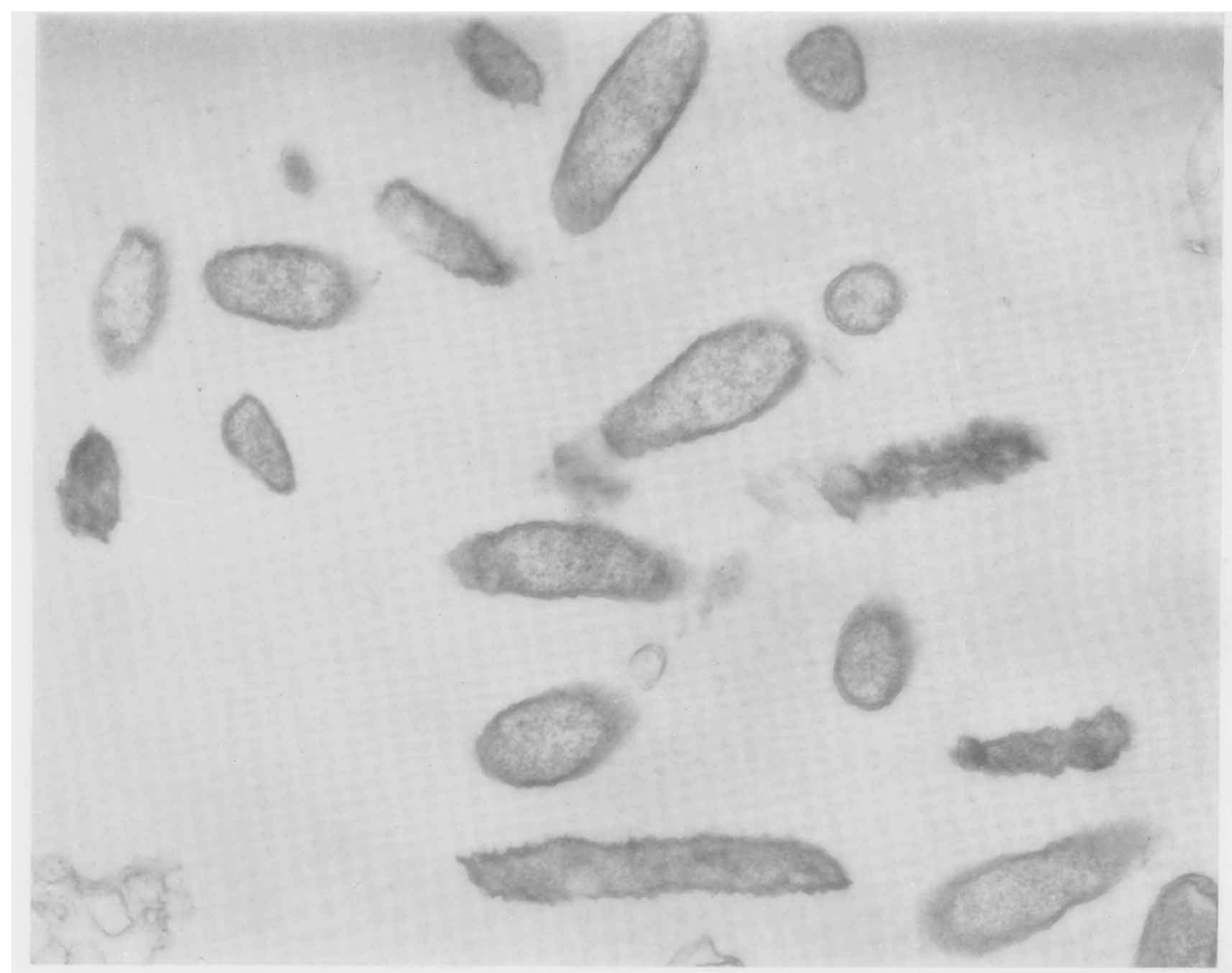

Fig. I

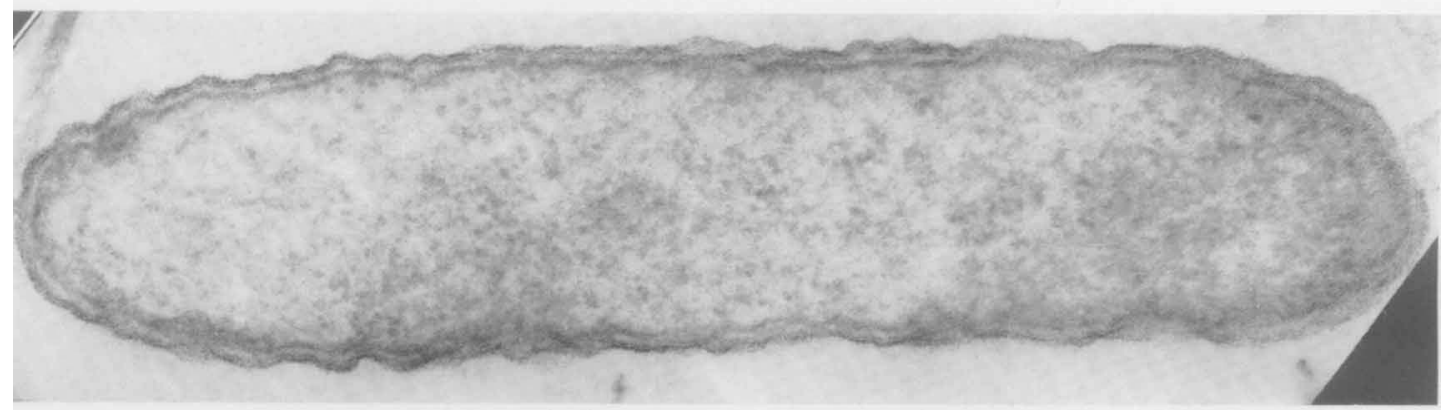

Fig. 2 
Schimdxraut, C. L., Marmur, J. \& Doty, P. (1962). Determination of the base composition of DNA from its buoyant density in CsCl. J. molec. Biol. 4, 430.

Strgel, R. W. (1954). Mate killing in Paramecium aurelia variety 8. Physiol. Zoöl. $27,89$.

SмrTH, J. E. (196I). Purification of kappa particles of stock 5 I of Paramecium aurelia. Am. Zool. I, 390.

Smtth-Sonneborn, J. E., Green, L. \& MARMUR, J. (1963). Deoxyribonucleic acid base composition of Kappa and Paramecium aurelia stock 51. Nature, Lond. 197, 385.

Soldo, A. T. (1963). Axenic culture of Paramecium. Some observations on the growth behaviour and nutritional requirements of a particle-bearing strain of Paramecium aurelia, 299. Ann N.Y. Acad. Sci. $108,380$.

SONNEBORn, T. M. (1950). Methods in the general biology and genetics of Paramecium aurelia. J. exp. Zool. Ir3, 87.

SONNEBORN, T. M. (1959). Kappa and related particles in Paramecium. Adv. Virus Res. 6, 229.

SteVEnson, I. (1967a). Diaminopimelic acid in the mu particles of Paramecium aurelia. Nature, Lond. 215, 434 .

Stevenson, I. (1967b). The biochemical capabilities of the $\mu$ particles of Paramecium aurelia stock 540. J. Protozool. 14, suppl. 43.

STEVENSON, I. (1967c). A method for the isolation of macronuclei from Paramecium aurelia. $J$. Protozool. 14, 412.

SuYama, Y. \& Preer, J. R., Jun. (1965). Mitochondrial DNA from Protozoa. Genetics 52, IO5I.

van Wagtendonk, W. J. \& TANGUay, R. B. (1963). The chemical composition of lambda in Paramecium aurelia stock 299. J. gen Microbiol. 33, 395.

van Wagtendonk, W. J., Clark, J. A. D. \& Godoy, G. A. (1963). The biological status of Lambda and related particles in Paramecium aurelia. Proc. natn. Acad. Sci. U.S.A. 50, 835.

WEISs, S. B. (1960). Enzymatic incorporation of ribonucleoside triphosphate into the interpolynucleotide linkages of ribonucleic acid. Proc. natn. Acad. Sci. U.S.A. 46, 1020.

Werss, S. B. (1962). Biosynthesis of ribopolynucleotides. Fed. Proc. Fedn Am. Socs exp. Biol. 21, 120.

\section{EXPLANATION OF PLATE}

\section{Plate I}

Fig. I. Low-power electron micrograph of a preparation of $\mu$ particles. Specimen preparation as detailed in the text. Shows $\mu$ particles in various stages of preservation-some are undergoing lysis. $\times 7500$.

Fig. 2. Higher-power electron micrograph of a single $\mu$ particle. Preparation as detailed in the text. The outer double membrane is clearly shown, as is the ill-defined appearance of the internal contents of the particle. $\times 40,000$. 